\title{
TŁUMACZENIE A INTERPRETACJA O NADWYŻKACH TREŚCI W TEKŚCIE DOCELOWYM
}

\begin{abstract}
Zarys treści. Artykuł definiuje nadwyżkę treści jako taki dodatkowy element tekstu docelowego, który posiada jedynie domniemany odpowiednik implicite w tekście wyjściowym. Nadwyżkę treści należy odgraniczyć z jednej strony od dodatkowych informacji będących efektem ubocznym dążenia do adekwatności tłumaczenia, z drugiej zaś od takich zamierzonych rozszerzeń treści oryginalnej, które zmieniają tekst docelowy w opracowanie lub wersję. Tak zdefiniowana nadwyżka treści okazuje się efektem subiektywnej interpretacji tekstu przez tłumacza. Szczegóły tej translatorskiej strategii zademonstrowano na przykładzie dwóch polskich tłumaczeń Après/ude G. Benna. Ostatecznie nadwyżkę treści uznano za element raczej niepożądany, zwłaszcza w tłumaczeniu literackim, gdzie interpretacyjna otwartość stanowi jedną z głównych wartości tekstu.
\end{abstract}

$\mathrm{N}$ aruszenie zasady adekwatności przekładu ${ }^{1}$ opisywane jest zwykle w kategoriach straty; dość wspomnieć tu potoczną dysjunkcję 'piękna' i 'wierności' tekstu docelowego (por. inne metafory straty w: Koller 1972: 52n.). W niniejszym artykule chciałbym się jednak zająć takimi sytuacjami, kiedy tekst docelowy wydaje się zawierać więcej informacji niż tekst wyjściowy. Mówiąc „wydaje się” dopuszczam możliwość, iż owa nadwyżka treści jest pozorna, nie rezygnując zarazem z próby rozpoznania autentycznych przypadków tekstu 'wzbogaconego', jak również opisania tegoż wzbogacenia przyczyn i skutków.

${ }^{1}$ Niniejszy tekst przyjmuje realistyczno-pragmatyczną koncepcję adekwatności przekładu, bliską poglądom wyrażanym przez K. Hejwowskiego $(2004: 58,73,94 n$.) 
Zacznijmy od przypadków, kiedy nadwyżka treści przy bliższej analizie okazuje się iluzoryczna, stanowiąc efekt uboczny starań tłumacza o adekwatność przekładu ${ }^{2}$. Za przykład niech posłuży jedno z polskich tłumaczeń słynnej repliki Susła, który na uwagę Alicji „But they were in the well” odpowiada: „Of course they were. Well in” (Carroll 1990: 154). Ta lakoniczna wypowiedź wymaga od tłumacza uwzględnienia co najmniej czterech aspektów, po równo rozdzielonych między sferę signifié i signifiant: dwuznaczności wyrazu 'well', intensyfikacji potwierdzenia przypuszczeń Alicji, chiastycznej konstrukcji pary pytanie-odpowiedź („in [the] well - well in”) i wreszcie rzeczonej lakoniczności. Spośród trojga polskich tłumaczy, którzy postanowili bezpośrednio zmierzyć się z tą mnogością aspektów, dwoje wykorzystało narzucającą się dwuznaczność polskiego wyrazu 'studnia', oddając oryginalną frazę poprzez: „Oczywiście że były. Już od stu dni” (Carroll 1990: 155, por. także Carroll 1999: 93). W ten sposób przekład ocalił komponenty 'dwuznaczność', 'intensyfikacja' i 'lakoniczność', rezygnując z oddania komponentu 'chiazm'. Wyjątkiem wśród tłumaczy okazał się natomiast Maciej Słomczyński, u którego czytamy: „Oczywiście że były. W studni na dole, dudni w stodole" (Carroll 1975: 82). Jak widać, autor zdecydował się tym samym na radykalne odwrócenie priorytetów, porzucając pierwsze trzy z wymienionych aspektów w imię ostatniego: chiastycznej struktury oryginału, która notabene w przekładzie oddana jest przez konstrukcję zwaną po niemiecku Schüttelreim, po polsku zaś określaną bardziej potocznie mianem 'gry półsłówek'. W całościowym rozrachunku, przy skądinąd dyskutowalnym założeniu, że wspomniane cztery aspekty są równoważne, strata przeważa zatem zysk w stosunku $3: 1$, dla naszych potrzeb spróbujmy jednak pominąć kwestię pominiętych wymiarów dzieła i potraktować rzecz tak, jakby chodziło rzeczywiście jedynie o efekt fonetycznej symetrii. Zostaje on niewątpliwie przez Słomczyńskiego oddany, przy tej okazji jednak na plan zostają wprowadzone zupełnie nowe komponenty: semantyczny (dudnienie w stodole) i fonetyczny (rozbudowane metrum, podwójny rym). Powstała w ten sposób nadwyżka treści jest jednak moim zdaniem jedynie ubocznym efektem dążenia do adekwatności przekładu; co za tym idzie, wynikające z niej sugestie odbioru (np. doszukiwanie się izotopii 'ludowość) powinny zostać 'uśpione' przez modelowego czytelnika (por. Eco 1994: 125n.). To samo dotyczy 'nadwyżek' podyktowanych potrzebą wyjaśnienia kontekstu.

\footnotetext{
${ }^{2}$ Por. pojawiające się w takich kontekstach ostrzeżenia przed „dodatkowymi informacjami” (Delisle et al. 2004: 74) i „niepożądanymi konotacjami” (Hejwowski 2004: 92).
} 
$\mathrm{Na}$ podstawie powyższego można już zdefiniować tytułowy fenomen jako taki element tekstu docelowego, który nie ma zarówno explicite, jak i implicite odpowiednika $\mathrm{w}$ tekście oryginalnym, przy czym pod pojęciem 'odpowiednik implicite' rozumie się te aspekty fonetyczne i semantyczne odpowiednika explicite, których w tłumaczeniu nie da się oddać w stosunku 1:1 i muszą być wyrażane za pomocą technik 'suplementarnych', takich jak: amplifikacja, eksplicytacja, peryfraza, przypis tłumacza czy rozbudowanie (por. Delisle et al. 2004: 23, 37, 73n., 79n. i 85). Zanim jednak przystąpimy do omawiania przykładów tak opisanego zjawiska, nie od rzeczy będzie dokonanie jeszcze jednego rozróżnienia, które pozwoli nam wytyczyć jego drugi, tym razem maksymalny punkt krytyczny. Chodzi o sytuacje, kiedy nadwyżka treści rozrasta się do tego stopnia, iż zyskuje wobec treści adekwatnych pozycję równorzędną lub wręcz dominującą. Można przyjąć, że od tego momentu nazywanie tekstu docelowego 'tłumaczeniem’ traci zasadność, adekwatniejszymi terminami stają się natomiast 'opracowanie', 'adaptacja', 'parafraza' czy 'wersja', innymi słowy zatem określenia takich tekstów pochodnych, przy których produkcji wytwarzanie nie posiadających pokrycia w oryginale nadwyżek treści przestaje być błędem w sztuce zyskując status czynności autorskiej wychodzącej poza przekład. Twory tego rodzaju zazwyczaj nie uzurpują sobie miana tłumaczeń (por. rozgraniczenie między tłumaczeniem a opracowaniem w: Schneider 1993: 121n. ${ }^{4}$; Snell-Hornby et al. 1999: 152 i dyskusję nad zasadnością określania adaptacji jako tekstu docelowego w: Dąmbska-Prokop 2000: 27n.) i uchodzą nader często za oryginalne dzieła adaptatorów ${ }^{5}$.

${ }^{3} \mathrm{~W}$ tym miejscu uznaję za stosowne podkreślić, że niniejszy artykuł nie rozważa nadwyżek treści w kategorii błędu w tłumaczeniu, co oczywiście jest również możliwe, jeśli wziąć pod uwagę, iż do rzeczonej kategorii należą także takie zjawiska, jak 'nadtłumaczenie’ (Delisle et al. 2004: 63) czy 'uzupełnienie’ (Delisle et al. 2004: 113). Por. jednakowoż także neutralne definicje obu terminów jako „technik tłumaczeniowych” (Lukszyn 1993: 199 i 383) oraz dyskusję nad zasadnością negatywnego wartościowania nadtłumaczenia (w: Dąmbska-Prokop 2000: 145n.). O „dodatkach” jako błędzie w sztuce przekładu literackiego zob. Hejwowski 2004: 144n.

${ }^{4}$ Spośród znanych mi publikacji praca Schneidera jest niewątpliwie najprecyzyjniejsza pod względem definicyjnym (por. s. 97-112) i typologicznym (por. s. 112-115 i 263-316).

${ }^{5}$ Jak np. Amalia i Rękawiczka, które, choć zaopatrzone w podtytule adnotacją „Z Szylera”, zaliczane są jednak do wierszy Mickiewicza; słusznie zresztą, gdyż ingerencje w tekst oryginału są - zwłaszcza w pierwszym przypadku - znaczne. Inna sprawa, że polegają one raczej na rekombinacji, substytucji i redukcji materiału wyjściowego, aniżeli na jego uzupełnieniu (por. Mickiewicz 1983: 20 i 62n.; Schiller 1981b: 85n. i 1981a: 151n.). 
Wyznaczony drogą obustronnego odgraniczenia przedział występowania właściwej nadwyżki treści powinien zatem obejmować takie przekłady, których treści dodane $\mathrm{z}$ jednej strony nie mają pokrycia $\mathrm{w}$ tekstach oryginalnych, z drugiej zaś nie są całkowicie wyzute z powiązań z tymiż tekstami. Sytuację taką najlepiej oddaje, moim zdaniem, opozycja pojęciowa zawarta w tytule niniejszego artykułu. W jej świetle za właściwą nadwyżkę treści uznać należy taki element przekładu, który jest ewidentnie świadectwem indywidualnej interpretacji danego elementu oryginału przez tłumacza. Innymi słowy, aby nawiązać do sformułowanej powyżej definicji, nadwyżka treści jest elementem tekstu docelowego, posiadającym jedynie domniemany odpowiednik implicite w tekście wyjściowym. Poniżej chciałbym przedstawić dwa przykłady takiego zjawiska, różniące się stopniem ingerencji interpretacyjnej, obszarem zastosowania i skutkami dla recepcji.

Pierwszy przykład jest znany i zwięzły, stanowi go bowiem polskie tłumaczenie tytułu rozprawy Zygmunta Freuda Das Unbehagen in der Kultur (1930) autorstwa Jerzego Prokopiuka (1967). Brzmi ono, jak wiadomo, Kultura jako źródło cierpień, stanowiąc tym samym, o ile się nie mylę, ewenement wśród innych przekładów (fr. Malaise dans la civilisation, ang. Civilization and its discontents, szw. Vi vantrivs $i$ kulturen). O ile te wymienione, pozwalając sobie wprawdzie na pewną swobodę składniowo-leksykalną (rosnącą w kolejności cytowania), starają się jednak oddać sens oryginału, o tyle tłumaczenie Prokopiuka stanowi przykład nadwyżki treści, u której podłoża leży - jak się zaraz okaże, nie do końca samowolna - interpretacja oryginału polegająca na dookreśleniu związku między 'cierpieniem' a 'kulturą'. W oryginale związek ten jest natury 'przestrzennej', mimo iż słowo 'Unbehagen' rządzi zasadniczo przyimkiem 'an', który faktycznie może sugerować kauzalność, Freud zdecydował się na bardziej neutralne 'in', ukazujące 'kulturę' jedynie jako środowisko występowania 'cierpienia'. Prokopiuk natomiast postawił kropkę nad 'i', sugerując zależność przyczynowo-skutkową między pierwszym a drugim. Jak już jednak wspomniałem, nie była to interpretacja nie mająca pokrycia w (ko)tekście. Lektura rzeczonej rozprawy uwidacznia bowiem, że choć Freud faktycznie wymienia w niej także dolegliwości występujące w kulturze, a zarazem z nią niepowiązane (por. Freud 1995: 31n.), to jednak głównym tematem tekstu są istotnie cierpienia wynikające $\mathrm{z}$ narzucanego przez kulturę stłumienia pierwotnych instynktów. Tym samym interpretacja Prokopiuka okazuje się wręcz lepiej trafiać w sedno, niż czyni to tytuł oryginału.

Zdecydowanie inaczej ma się rzecz z przykładem, któremu chciałbym poświęcić nieco więcej miejsca. Chodzi o dwa polskie tłumaczenia Aprèslude, 
wiersza Gottfrieda Benna z 1955 roku. Poniżej przytaczam oryginał i obie polskie wersje.

Tekst Wy Jściowy (TW)

Tauchen mußt du können, mußt du lernen, einmal ist es Glück und einmal Schmach, gib nicht auf, du darfst dich nicht entfernen, wenn der Stunde es an Licht gebrach.

Halten, Harren, einmal abgesunken, einmal überströmt und einmal stumm, seltsames Gesetz, es sind nicht Funken, nicht alleine - sieh dich um:

Die Natur will ihre Kirschen machen selbst mit wenig Blüten in April hält sie ihre Kernobstsachen bis zu guten Jahren still.

Niemand weiß, wo sich die Keime nähren, niemand, $\underline{\mathrm{ob}}$ die Krone einmal blüht Halten, Harren, sich gewähren Dunkeln, Altern, Aprèslude.

(G. Benn 1988: 469)

TeKsT DOCELOWY 1 (TD1)

Musisz pogrążyć się i musisz nauczyć: raz tylko szczęście i tylko raz hańba, +1 (wzmocnienie nie wyparłeś się siebie, nie musisz więc uciec związku) przed sobą, gdy załamie się godzina światła. +1 (skutek)

Stój, wstrzymaj się, raz tylko upadek, raz pogrążenie, $\underline{i}$ tylko raz niemota, niezwykłe prawo, które nie iskrą nawet,

nawet nie tym - $\underline{\text { tylko }}$ mu się przypatrz.

natura kościoły [sic!] swe wznosiła +1 (cecha charakteryzująca)

+1 (wyjątkowość $\times 2)$

+1 (warunek)

-1 (przezwyz garsteczki tylko kwiatów, w kwietniu, ciężenie) przechowując swoje pestki i nasiona aż do dobrego, cichego roku przyjścia. 
Nikt nie wie, gdzie się kiełki żywią, nikt, czy korona drzew zakwitnie jeszcze kiedy stój, wstrzymaj się, by działała $+1(\underline{\text { cel }})$ ciemność, starość, aprèslude [sic!].

(G. Benn 1982: 80)

\section{TeKst DOCELOWY 2 (TD2)}

Musisz potrafić nurkować, musisz się nauczyć raz będzie wielkie szczęście, a raz wielka hańba, nie rezygnuj, nie wolno ci bezmyślnie tchórzyć, kiedy krótkiej godzinie braknie nagle światła.

Musisz wytrzymać, przetrwać chociaż raz upadłeś, +1 (przezwycię-

-1 (wzmocnieraz dławiła cię woda, raz wielkie milczenie, żenie) nie związku)

dziwne prawo, to nie są przecież zwykłe iskry, +1 (uzasadnienie) $\underline{\text { w każdym razie nie tylko, odwróć się za siebie: +1 (ogranicze- }}$ nie negacji)

Przyroda chce, by w lecie dojrzewały wiśnie $\quad+1$ (cel) i nawet jeśli wiosną było kwiatów mało, przez mrozy i wichury chroni w pestkach życie, -1 (czas trwania) po to, by drzewo w słońcu znów owocowało. $\quad+1$ (cel)

Nikt nie wie, gdzie się żywią delikatne kiełki, nikt, czy korona drzewa będzie białym cudem. Musisz wytrzymać, przetrwać, musisz mieć nadzieję

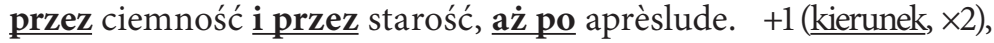
(G. Benn 1987) +1 (czastrwania)

Chciałbym pominąć tu niedostatki warsztatowe tłumaczeń, zwłaszcza pierwszego z nich, i skoncentrować się na jednym tylko aspekcie, analizowanym już na przykładzie tytułu pracy Freuda. Chodzi o wytwarzanie w procesie tłumaczenia nieobecnych w oryginale związków i zależności. Proceder ten został uwidoczniony w sposób następujący: w tekście oryginału podkreśleniem zaznaczono wszystkie spójniki, przyimki, zaimki oraz partykuły stwarzające powiązania między sąsiadującymi partiami. Zabieg ten został powtórzony na tekstach tłumaczeń, z tym że wyrazy tworzące związki nieobecne w oryginale zostały dodatkowo wytłuszczone; ponadto na prawym marginesie dana nadwyżka została odnotowana symbolem ‘ +1 ' wraz z określeniem semantycznego charakteru wytworzonego związku. Jeżeli dany 
związek uznano za nadwyżkę treści, określenie owo dodatkowo podkreślono. Gwoli kompletności mniej liczne przypadki odwrotne, tj. usunięcia obecnego w oryginale elementu 'związkotwórczego', odnotowane zostały na lewym marginesie symbolem '-1', także opatrzonym opisem. Jedyny przypadek substytucji (TD2, w. 12) nie został specjalnie zaznaczony, toteż zwracam na niego uwagę niniejszym zdaniem.

Jak widać, mimo znacznej różnicy między generalną adekwatnością tłumaczeń (na korzyść TD2) oba zbliżają się do siebie, jeśli chodzi o jeden specyficzny rodzaj semantycznej nadprodukcji lub, aby użyć terminologii K. M. van Leuven-Zwart, „semantyczno-syntaktycznej modyfikacji” (Leuven-Zwart van 1989: 166n.; 1990: 78n.): o ile dominującą cechą składni oryginału jest parataksa, a jej semantycznym efektem fragmentaryczność doświadczeń (widoczna zwłaszcza w wyliczeniach wersów 5-6 i 15-16 oryginału), o tyle oba tłumaczenia 'wzbogacają pierwotny tekst o siatkę różnorakich powiązań, nadających zatomizowanej strukturze wrażenie sensownie zorganizowanego uniwersum. Aby upewnić się co do trafności tej diagnozy możemy przetestować trzy hipotezy alternatywne:

- 'Związkotwórczość' jest ubocznym efektem dążenia do adekwatności fonetycznej, czyli stanowi dodatek porównywalny z innymi elementami służącymi do wyrównania rytmu czy dopasowania rymu (np. „będzie białym cudem” w TD2, w. 14 jako ekwiwalent „einmal blüht”). Na niekorzyść tej hipotezy przemawia jednak TD1, którego autor o rym i o rytm zanadto się nie troszczy, a mimo to liczbą omawianych dodatków dorównuje autorce TD2.

- 'Związkotwórczość' jest koniecznym efektem dążenia do adekwatności gramatycznej, innymi słowy parataktyczność oryginału jest pozorna, porównywalna $\mathrm{np}$. $\mathrm{z}$ angielskimi konstrukcjami absolute infinitive (Prejbisz et al. 1984: 282) czy nominative absolute (Prejbisz et al. 1984: 290n.). Mimo iż w języku niemieckim istnieją porównywalne struktury (np. dla wyrażenia imiesłowu przysłówkowego uprzedniego), w danym wypadku hipotezę tę możemy jednak całkowicie wykluczyć: specyfika składniowa wszystkich uzupełnionych fragmentów ma swoje odpowiedniki w polszczyźnie, co częściowo potwierdza już porównanie poszczególnych rozwiązań zastosowanych w TD1 i TD2.

- 'Związkotwórczość' jest wynikiem trafnego odczytania ukrytego znaczenia utworu, czyli stanowi dodatek porównywalny z precyzująca translacją Das Unbehagen in der Kultur. Problem w tym, że w tym wypadku nie dysponujemy ani tekstem towarzyszącym, który pozwoliłby 
na weryfikację hipotezy ${ }^{6}$, ani nawet takowego tekstu wyobrażeniem: od dawna bowiem pożegnaliśmy się $\mathrm{z}$ wiarą $\mathrm{w}$ istnienie autorytatywnych (choćby nawet odautorskich) interpretacji tekstów literackich (por. np. Burzyńska 2003).

W rezultacie możemy ostatecznie stwierdzić, iż w omawianym wypadku istotnie mamy do czynienia $\mathrm{z}$ zasadniczym przedmiotem niniejszego artykułu. Obu tekstom nie można z jednej strony odmówić miana mniej (TD1) lub bardziej (TD2) udanych tłumaczeń, z drugiej strony ewidentna jest w nich obecność interpretacyjnych nadwyżek treści. Ich występowanie w powstałych niezależnie od siebie tekstach skłania ku pytaniom o ponadindywidualne przyczyny zjawiska, czy to natury lingwistycznej (większe zapotrzebowanie polszczyzny na sygnały spójności?) ${ }^{7}$, czy też kulturowej (większe skłonności do kontrukcji całościowego obrazu świata w kulturze polskiej?), które z braku reprezentatywnego materiału mogą tu być jedynie zasygnalizowane. Fakt, iż podobne zjawisko zostało zaobserwowane także w poetyckich tekstach docelowych sporządzonych w innych językach i podobnie opisane jako przejęcie przez tłumacza funkcji (nieobecnego w tekście wyjściowym) wyjaśniającego narratora (por. Leuven-Zwart van 1990: 81; Tabakowska 2001: 89n.) skłania jednak bardziej ku przypuszczeniu, iż mamy tu do czynienia ze zjawiskiem polegającym na - dokonywanym zazwyczaj w dobrej wierze, tj. ku wygodzie czytelnika - arbitralnym przesunięciu granicy między koniecznym wyjaśnieniem logicznych związków sugerowanych przez język lub kulturowy kontekst oryginału a subiektywną interpretacją dostatecznie już czytelnego tekstu (por. Leuven-Zwart van 1990: 89n.). Za podstawową przyczynę owego przesunięcia należy uznać

${ }^{6}$ Nie jest to zupełnie ścisłe w odniesieniu do TD2: tłumaczenie owo nie powstało bowiem w ramach samodzielnej publikacji utworów Benna, lecz stanowi część psychologiczno-kulturowego studium o samobójstwie; wśród wielu cytowanych tak utworów literatury pięknej jego autor przytacza także Aprèslude jako przykład utworu „antysuicydalnego” (Ringel 1987: 219), dając tym samym sugestię interpretacyjną, o której zaakceptowaniu przez tłumaczkę mogą świadczyć także 'budujące' efekty użycia niektórych elementów 'związkotwórczych' (w. 5, 8, 12, 16). Jednak nawet jeśli interpretację Ringela uznamy za 'adekwatną', nie musi to oznaczać koniecznej akceptacji dla syntetyzacji struktury utworu. Wręcz przeciwnie, zatomizowany oryginał potwierdza reputację Benna jako 'nihilisty', czyniąc pozytywne przesłanie utworu bardziej zaskakującym, a może nawet bardziej przekonującym.

${ }^{7}$ Por. rozważania na temat większego potencjału kohezyjnego zaimków angielskich w porównaniu z polskimi i wynikającą z niego konieczność wprowadzania „nadmiarowych" informacji w przekładzie w: Dąmbska-Prokop 2000: 214. 
błędne rozstrzygnięcie dylematu, czy syntaktyczne niedookreślenie tekstu docelowego wynika $z$ analogicznej cechy tekstu wyjściowego, czy też jest wymagającym korekty niedostatkiem aktualnej wersji przekładu. Ponieważ zaś wzmożone występowanie miejsc niedookreślenia jest charakterystyczne dla tekstów poetyckich, problemu nadwyżek treści można spodziewać się częściej w przekładach literatury 'pięknej'.

Mimo niezaprzeczalnej słuszności poglądu, że każde tłumaczenie konstruuje na nowo swój przedmiot (por. Zima 1992: 199n.; Tabakowska 2001: 102 i polemicznie Schneider 1993: 42n.), powyższe analizy wykazały, iż zniuansowanie owych konstrukcji pod względem stopnia innowacji jest nie tylko konieczne, ale i stosunkowo łatwe do przeprowadzenia. Jeśli chodzi o wartościowanie tłumaczeń zawierających nadwyżki treści, powinno być ono zróżnicowane w zależności od systemowej specyfiki oryginału. O ile w tekstach 'nieliterackich' doprecyzowanie czy nawet uzupełnienie znaczenia może zostać uznane za faktyczne wzbogacenie, o tyle w tekstach literackich, z natury bardziej 'otwartych', doprecyzowanie takie przynosi uszczerbek ich polisemiczności (por. Leuven-Zwart van 1990: 81). Nadwyżki treści prowadzą tu paradoksalnie do ubytku funkcji i z tego powodu powinno się ich unikać, co z pewnością wymagać będzie dużego samozaparcia od tłumacza, który jako pośrednik między kulturami musi odczuwać naturalną dążność do maksymalnej eksplikacji Innego.

\section{Literatura}

Benn, G., 1982, Poezje wybrane, tł. Krzysztof Karasek, Warszawa.

Benn, G., 1987, „Aprèslude”, przeł. L. Barańska, [w:] E. Ringel, Gdy życie traci sens. Rozważania o samobójstwie, przeł. E. Kaźmierczak, Szczecin, s. 219.

Benn, G., 1988, Gedichte in der Fassung der Erstdrücke, Frankfurt/M.

Burzyńska, A., 2003, „Teoria i lektura: niebezpieczne związki”, Pamiętnik Literacki, XCIV, z. 1, s. 71-109.

Camus, A., 1985, Obcy, tł. M. Zenowicz, Warszawa.

Carroll, L., 1975, Przygody Alicji w Krainie Czarów/O tym, co Alicja odkryła po drugiej stronie lustra, tł. M. Słomczyński, Warszawa.

Carroll, L., 1990, Alice's Adventures in Wonderland/Przygody Alicji w Krainie Czarów, tł. R. Stiller, Warszawa. 
Carroll, L., 1999, Alicja w Krainie Czarów, tł. J. Kozak, Warszawa.

Dąmbska-Prokop, U. (red.), 2000, Mała encyklopedia przekładoznawstwa, Częstochowa.

Delisle, J., Lee-Jahnke, H., Cormier, M. C. (red.), 2004, Terminologia tłumaczenia, tł. T. Tomaszkiewicz, Poznań.

Eco, U., 1994, Lector in fabula. Wspótdziałanie w interpretacji tekstów narracyjnych, przeł. P. Salwa, Warszawa.

Freud, S., 1972, Das Unbehagen in der Kultur/Abriß der Psychoanalyse, Frankfurt/M.

Freud, S., 1995, Kultura jako źródło cierpień, tł. J. Prokopiuk, Warszawa.

Hejwowski, K., 2004, Kognitywno-komunikacyjna teoria przekładu, Warszawa. Koller, W., 1972, Grundprobleme der Übersetzungstheorie, Bern-München.

Leuven-Zwart, K. M. van, 1989, „Translation and Original. Similiarities and Dissimiliarities, I", Target 1: 2, s. 151-181.

Leuven-Zwart, K. M. van, 1990, „Translation and Original. Similiarities and Dissimiliarities, II", Target 2: 1, s. 69-95.

Lukszyn, J.(red.), 1993, Tezaurus terminologii translatorycznej, Warszawa.

Mickiewicz, A., 1983, Wiersze (=Dzieła poetyckie I), Warszawa.

Prejbisz, A., Jasińska, B., Kryński, St., 1984, Gramatyka angielska w ćwiczeniach, Warszawa.

Reszke, R., 1995, „Nota redakcyjna”, [w:] S. Freud, 1995, Kultura jako źródło cierpień, tł. J. Prokopiuk, Warszawa, s. 160.

Ringel, E., 1987, Gdy życie traci sens. Rozważania o samobójstwie, przeł. E. Kaźmierczak, Szczecin.

Schiller, F., 1981a, Gedichte. Prosaschriften (=Werke in fünf Bänden 1), Berlin-Weimar.

Schiller, F., 1981b, Die Räuber/Die Verschwörung des Fiesko zu genua/Kabale und Liebe (=Werke in fünf Bänden 2), Berlin-Weimar.

Schneider, M., 1993, Übersetzung und Bearbeitung: zur Differenzierung und Abgrenzung des Übersetzungsbegriffs, Tübingen.

Snell-Hornby, M., Hönig, H. G., Kußmaul, P., Schmitt, P. A. (red.), ${ }^{21999, ~ H a n d-~}$ buch Translation, Tübingen.

Tabakowska, E., 2001, Językoznawstwo kognitywne a poetyka przekładu, Kraków.

Zima, P. V., 1992, Komparatistik. Einführung in die Vergleichende Literaturwissenschaft, Tübingen. 


\section{Translation vis-á-vis interpretation. Content excess in the target text (summary)}

The paper defines content excess as a supernumerary element of the target text which is supposed to have an implicit equivalent in the source text. The content excess is different from those additional elements in the target text which accompany searching for adequacy, i.e. represent implicit elements in the source text that have to be translated explicitly due to linguistic or cultural reasons. On the other hand, the content excess in the target text has to be differentiated from an addition that (through its size or relevance) deliberately alters the translated text into an adaptation or a different version. This definition of the content excess must be perceived as a result of subjective text interpretation. The analysis of two Polish translations of Gottfried Benn's late poem Apreslude provides a detailed example of a translation approach which, as the conclusion suggests, should rather be avoided, particularly in literary translation where the interpretive openness is one of the primary text values. 